\title{
The Constitutionality of Statutory Criminal Presumptions $\dagger$
}

Statutory criminal presumptions can aid a prosecutor in securing convictions and provide incentive to the accused to produce evidence. However, by lightening the criminal burden of proof, by providing opportunity for prosecutions on insubstantial evidence, or by requiring inconsistent jury instructions, such presumptions may collide with a number of constitutional principles-among them due process notions of fairness, established views of the proper functions of judge and jury, the right to a jury trial itself, and the privilege against self-incrimination. ${ }^{1}$ 'This comment undertakes to examine the Supreme Court's recent attempts to resolve these tensions in the use of statutory criminal presumptions. ${ }^{2}$

A principal source of confusion is the frequent failure of courts and legislatures to specify the impact of a rebuttable criminal presumption on the admissibility of evidence, the burden of going forward with evidence, and the burden of persuasion. When treated as permitting an inference $^{3}$ (the basic fact is to be submitted to the jury only as some evidence of the presumed fact), the presumption disadvantages the accused no more than he would have been absent the presumption, unless the basic fact would otherwise have been excludable, which is rare, or unless the judge is required to call special attention to the inference in his instructions. When a presumption describes prima facie evi-

$\dagger$ David N. Brown, J.D. 1966, The University of Chicago. The author wishes to thank Professor Bernard D. Meltzer for his most helpful criticism and suggestions during the preparation of this comment.

1 Criminal presumptions are treated in 1 JONEs, Evionence $\$ \S 9-119$ (5th ed. 1958); MCCormick, Evidence 635-72 (1954); Brosman, The Statutory Presumption, 5 Tul. L. REv. 178, 196-202 (1931); Keeton, Statutory Presumptions-Their Constitutionality and Legal Effect, 10 TEXAs L. REv. 34, 43-50 (1931); Orfield, Burden of Proof and Presumptions in Federal Criminal Cases, 31 U. KAN. CrTY L. REv. 30 (1963); Note, Tot v. United States: Constitutional Restrictions on Statutory Presumptions, 56 HARv. L. REv. 1324 (1943); Note, 55 Colum. L. REv. 527, $541-47$ (1955).

2 United States v. Romano, 382 U.S. 136 (1965); United States v. Gainey, 380 U.S. 63 (1965).

3 United States v. Ross, 92 U.S. 281, 284 (1875). For a complete catalogue of meanings of both civil and criminal presumptions see Laughlin, In Support of the Thayer Theory of Presumptions, 52 MICH. L. REv. 195 (1953); Keeton, supra note 1. 
dence $^{4}$ in the sense that the basic fact, if found to exist, is sufficient evidence of the presumed fact to support a verdict of guilty and the jury is so instructed, the accused is disadvantaged only insofar as the quantum of evidence necessary to support a verdict of guilty may be lessened. In addition, a presumption may allow or require an instruction that the jury is "authorized" to find the presumed fact from the basic fact. This will probably tend to persuade the jury that the presumed fact does exist, and is especially important in those jurisdictions where comment on the evidence is otherwise prohibited.

A third possible impact of a presumption is that, upon production by the prosecutor of evidence of the basic fact, the burden of going forward with evidence negativing the presumed fact shifts to the accused, ${ }^{5}$ and failure to carry the burden results in foreclosure of the issue against the accused. The effect of shifting this burden is to place the risk of nonproduction upon the accused $;{ }^{6}$ and the extent of this risk depends upon the quantum of evidence necessary to carry the burden. ${ }^{7}$ Apparently because foreclosure seems to be a harsh penalty it has seldom been employed in criminal cases. ${ }^{8}$

Finally, a presumption can mean that proof of the basic fact shifts to the accused the burden of persuasion as to the presumed fact. ${ }^{9}$ Such a shift places upon the accused the risk of non-persuasion of the jury. ${ }^{10}$ However, a shift in this burden is almost always accompanied by a shift in the burden of going forward. ${ }^{11}$

Prior to Tot $v$. United States ${ }^{12}$ the Supreme Court appeared to have adopted two alternative tests to aid in determining the constitutionality of criminal presumptions, and a third test seemed incipient. ${ }^{13}$ The "ra-

4 E.g., Luria v. United States, 231 U.S. 9, $26-27$ (1913); Bailey v. Alabama, 219 U.S. 219, 238-39 (1911).

5 E.g., Casey v. United States, 276 U.S. 413 (1928) (semble).

6 See 9 Wrgmore, EVIDENCE $\S \S 2487,2489,2491$ (3d ed. 1940).

7 The quantum of evidence necessary to rebut the presumption and whether judge or jury should determine when it has been rebutted has been the subject of much debate. See generally Keeton, supra note I; Laughlin, supra note 2.

8 See text accompanying notes 80-82 infra. The Reporter for the MODEL PENAL CODE proposed the use of foreclosure but this was not adopted, MODEL PeNal CoDE, \& 1.13 at 8-9, comment at 116-17 (Tent. Draft No. 4, 1955). In contrast is the general practice in civil cases, where the normal consequence of failure to discharge the burden of going forward is foreclosure of the issue against the failing party.

9 E.g., Morrison v. California, 291 U.S. 82, 96 (1934); Yee Hem v. United States, 268 U.S. 178 (1925); Hawes v. Georgia, 258 U.S. 1 (1922). These cases shifted both burdens.

10 See 9 WIGMORE, EVIDENCE $\$ 2485$ (3d ed. 1940).

11 See authorities cited note 9 supra.

12319 U.S. 463 (1943).

13 In apparent recognition of the complexity of presumptions the Court has eschewed the notion that there is any single determinative test. See Morrison v, California, 291 U.S. 82 (1934). 
tional connection" test, which had been applied to the latter three of the foregoing varieties of presumptions, ${ }^{14}$ required the existence of a probative relation between the presumed fact and the basic fact such that the existence of the basic fact made more probable than not the existence of the presumed fact. ${ }^{15}$ The "comparative convenience" test had received its only application in Morrison $v$. California, in which the Court struck down a state statute making it a crime to conspire to put an alien in possession of land and shifting to the accused the burdens of persuasion and going forward with evidence as to the citizenship of his alleged co-conspirator. ${ }^{16}$ This test required that "upon a balancing of convenience or of the opportunities for knowledge the shifting of the burden will be found to be an aid to the accuser without subjecting the accused to hardship or oppression."17 The third test, devised by $\mathrm{Mr}$. Justice Holmes and applied only in one civil case, required analysis of the elements of the statute creating liability; if the element which the presumption is designed to help establish could have been omitted or replaced by the basic fact without impairing the statute's constitutionality, then the presumption was likewise constitutional. ${ }^{18}$

The Court in Tot put an apparent end to the development of these three tests as alternatives, establishing the rational connection standard as paramount with comparative convenience as a corollary and expressly rejecting the Holmes test in its entirety. ${ }^{19}$ Tot had been convicted under the Federal Firearms Act making it unlawful for one previously convicted of a crime of violence to receive any firearm in interstate commerce after June 30, 1938 and providing that "possession of a firearm ... by any such person shall be presumptive evidence that such firearm ... was ... received ... by such person in violation of

14 E.g., Luria v. United States, 281 U.S. 9 (1913) (prima facie); Casey v. United States, 276 U.S. 413 (1928) (burden of going forward); Yee Hem v. United States, 268 U.S. 178 (1925) (burden of persuasion). On the ambiguity of the term "rational connection" see MCCoRAIICK, supra note 1 , at 659-63.

15 See Yee Hem v. United States, 268 U.S. 178 (1925).

16291 U.S. 82 (1934).

17 Id. at 89 .

18 Ferry v. Ramsey, 277 U.S. 88 (1928). McCormick notes two other possible tests which had received only very uncertain recognition by the courts. First was Wigmore's view that any presumption was constitutional if its only effect was to shift the burden of going forward, because the defendant can always introduce evidence and the jury can be relied upon to evaluate the resulting record fairly. Second was the very ambiguous test in Westesn \& A. R.R. v. Henderson, 279 U.S. 639 (1929), which "appears to gauge the validity of the presumption there involved by the effect given to it at the trial." The presumption was given weight as evidence, and the Court struck it down as arbitrary. MCCoRMICK, supra note 1 , at 654-63.

19319 U.S. at 467-68, 472; see McCorMick, supra note 1, at 654-63. 
this Act."20 The only evidence adduced by the Government was that on September 20,1938, Tot was found to be in possession of a firearm, and that he had previously been convicted of assault and battery. ${ }^{21}$ The Court held that there was insufficient rational connection between possession of a firearm on September 20, 1938 and interstate receipt after June 30,1938 , and thus the presumption was an unconstitutional deprivation of due process. ${ }^{22}$

Unfortunately the Court did not specify which of the functional definitions of presumption was applicable to the Tot presumption. In fact the opinion mentioned all four types; and because of this ambiguity the decision lends itself to a variety of interpretations.23 It is possible to read the case as being primarily concerned with presumptions which depend upon the jury to give effect to an inference from the basic fact to the presumed fact. ${ }^{24}$ Such is the situation when the presumption prescribes a prima facie case. Requiring a rational connection would then seem to reflect the view that it is unhealthy for the jury to be given discretion to find the existence of the facts irrationally, as it would be if a case were allowed to go to the jury when the state of the evidence was such that no rational jury would find the relevant facts to exist. This reading of the case requires recognition that due process includes the notion of rational control of the jury by the judge, a new though not necessarily misplaced principle of due process. Even the Tot rule, however, was not completely consistent with rational control of the jury by the judge. Dictum in Tot indicated that the rational connection between the basic and presumed fact could be less than an inference beyond a reasonable doubt, but the presumption could still be constitutional. ${ }^{25}$ Hence the judge might be compelled by the presumption to submit an issue of fact to the jury although the state of the evidence was such that no rational jury could find the presumed fact to exist beyond a reasonable doubt.

Another interpretation of Tot finds its origin in the Court's apparent concern for protecting persons from the harassment by prosecutors which could result if the state were required to produce evidence only as to some issues before the burden of going forward with evidence as to the remaining issues shifted to the accused. Thus the Court rejected

\footnotetext{
2052 Stat. 1250 (1938).

21319 U.S. at 464.

22 Id. at 467-68.

23 See Note, Tot v. United States: Constitutional Restrictions on Statutory Presumptions, 56 HAARV, L. REv. 1324 (1943).

24319 U.S. at 467.

25 The opinion is unclear as to how much evidence is required by the national connection test, although it does indicate in dictum that a presumption could be "created upon a view of relation broader than that a jury might take in a specific case." Id. at 468 .
} 
comparative convenience as an independent test for allocating the burden because the defendant always has easier access to the relevant facts. ${ }^{26}$ The rational connection test is consistent with this underlying policy since its application would assure that the state adduce a minimum quantum of evidence tending to establish the existence of any presumed fact before the burden of going forward with evidence of its non-existence is shifted to the accused. Thus insistence upon a rational connection would provide the accused some protection against the temptation of prosecutors aided by a presumption to institute proceedings when there is insufficient reason to believe that the accused committed the crime. This rationale would appear to apply with equal force to presumptions whose effect is to prescribe a prima facie case; indeed, a rational connection had always been required in such cases before Tot. ${ }^{27}$

There is no doubt that requiring a rational connection would mitigate harassment, but other less restrictive standards might yield the same result. One could, for example, judge presumptions according to whether they required the prosecution to come forward with evidence on such elements of the crime as would cast suspicion on the accused in the eyes of a reasonable man. ${ }^{28}$ However, such standards would be difficult to articulate and apply, ${ }^{29}$ and it is doubtful that the Court even considered alternatives since the rational connection test presented a ready-made solution.

The decision in Tot is particularly unclear with regard to the status of presumptions which shift the burden of persuasion. There is no danger that such a presumption would become a vehicle of harassment providing the burden of going forward remains upon the state, for until the state has adduced evidence upon which a rational jury could find guilt beyond a reasonable doubt the accused is entitled to a directed verdict of acquittal. After that burden has been carried a shift in the burden of persuasion would provide additional incentive beyond that provided by the mere introduction of evidence of guilt for the accused to produce whatever evidence he may have. Nor would there

28 "If [the argument from comparative convenience] were sound, the legislature might validly command that the finding of an indictment, or mere proof of identity of the accused, should create a presumption of the existence of all the facts essential to guilt." 319 U.S. at 469. See McCorMIcK, supra note 1, at 661-62.

27 Authorities cited note 4 supra. See also Western \& Atl. R.R. v. Henderson, 279 U.S. 639, 642 (1929) (civil case).

28 Cf. Model Penal Code, § 1.13, comment at 111, 116-17 (Tent. Draft No. 4, 1955). This is apparently the rationale upon which the constitutionality of affirmative defenses is predicated, see Leland v. Oregon, 343 U.S. 790, 799 (1952), and accords with ancient notions of malum in se.

29 See MCCormick, supra note 1 , at 659-63. 
be any problem of rational jury control, since the jury is not afforded the opportunity to find guilt beyond a reasonable doubt on the strength of the presumption. Several prior cases, however, held that a rational connection was required in order to shift the burden of persuasion, ${ }^{30}$ and while Morrison suggested that comparative convenience was sufficient to justify such a shift, ${ }^{31}$ Tot expressly reinterpreted that case to mean that comparative convenience was a necessary but not sufficient condition. $^{32}$ The necessary implication of this position is that the location of the burden of persuasion is a constitutional matter. The burden must be upon the state initially and may not be shifted until the constitutional tests of Tot are satisfied. Although the source of this principle was presumably the due process clause, ${ }^{33}$ it is difficult to perceive any more precise underlying policy than the vague notion of fairness to the criminal accused.

A further troublesome feature of the Tot opinion was the omission of any discussion of affirmative defenses, which are different from presumptions, if at all, only in that both burdens are placed upon the accused at the outset. ${ }^{34}$ Allocation at the outset is functionally equivalent to shifting the burdens as to the defensive elements upon the prosecution's having adduced sufficient evidence on all other elements to withstand a motion for a directed verdict of acquittal. The most familiar affirmative defenses are insanity and self-defense, and it can hardly be maintained that there is any compelling inference of the accused's sanity or aggressive posture from the fact that he has committed an intentional homicide. ${ }^{35}$ Although consistency would thus seem to demand that the court strike down such allocations of burden, in Leland $v$. Oregon the Court held constitutional a statute placing upon the accused the burden of going forward and the burden of persuasion beyond a reasonable doubt on the issue of sanity. ${ }^{36}$ Tot was distinguished on the grounds that the basic fact there was "neither criminal in itself nor an element of the crime charged." 37 As suggested previously, these factors might serve as an alternative constitutional standard to that espoused in $\operatorname{Tot}^{38}$ while protecting equally well

30 E.g., Western \& Atl. R.R. v. Henderson, 279 U.S. 639 (1929) (civil); Yee Hem v. United States, 268 U.S. 178 (1925); Hawes v. Georgia, 258 U.S. 1 (1922); Wilson v. United States, 162 U.S. 613 (1896).

31291 U.S. 82, 89, 96 (1934).

32319 U.S. at $469-70$.

33319 U.S. at 467.

34 Cf. Moder Penal Code, § 1.13, comment at 110-12, 116-17 (Tent. Draft No. 4, 1955).

35 Id. at 111.

36343 U.S. 790 (1952).

37 Id. at 799.

38 See United States v. Fleischman, 389 U.S. 349 (1950). 
against harassment. They do not, however, point to any significant difference in the effects of presumptions and affirmative defenses.

The final difficulty with Tot was the manner in which the Court rejected the Holmes test. It was argued that since Congress could have made possession of all firearms by former felons a crime, in order to protect interstate commerce it could do less and punish only those who could not show that the weapon possessed was not acquired in interstate commerce. The Court's reply was quite unclear but implied that it was only the statute enacted with which the Court could be concerned, not the potential power of the legislature. ${ }^{39}$ Why this should be so is certainly not self-evident, but there is a stronger argument for rejecting the Holmes test than that put forth by the Court. Even the proponents of the test recognize that determining the minimum facts for which the state can constitutionally impose liability is a very difficult task for which only the vaguest standards exist. ${ }^{40} \mathrm{It}$ is thus perhaps excusable for the Court to eschew a test which would involve such an inquiry. Moreover, this test, applied without regard to the inferential strength of the presumption or its procedural consequences, could sustain presumptions having defects similar to presumptions based solely on comparative convenience. In particular, rational control of the jury would be difficult should the basic and presumed facts lack probative relation when the presumption prescribes a prima facie case. Consider the plight of a judge attempting to instruct a jury when the presumed fact is an element of the offense but the evidence presented tends only to establish an empirically unrelated basic fact. This difficulty would not be present, however, when the presumption shifts one of the burdens of proof and the jury is instructed only as to the shift and not as to any inference. It must also be conceded that neither of the objections to the Holmes test approaches constitutional stature; they are matters of judicial convenience. The logic of his position is unassailable.

The understanding of the state of law after Tot $v$. United States is most clearly reflected in the Model Penal Code, which provides:

When the Code establishes a presumption with respect to any fact which is an element of an offense, it had the following consequences:

(a) when there is evidence of the facts which give rise to

39 "[I]t is plain that Congress ... did not seek to pronounce general prohibition of possession by certain residents of the various states of firearms in order to protect interstate commerce, but dealt only with their future acquisition in interstate commerce." 319 U.S. at 472. See Note, 55 Colum. L. REv. 527, 534 (1955).

40 See Note, 55 Colum. L. Rev. 527, $544-45$ (1955). 
the presumption, the issue of the existence of the presumed fact must be submitted to the jury, unless the Court is satisfied that the evidence as a whole clearly negatives the presumed fact; and,

(b) when the issue of the existence of the presumed fact is submitted to the jury, the Court shall charge that while the presumed fact must, on all the evidence, be proved beyond a reasonable doubt, the law declares that the jury may regard the facts giving rise to the presumption as suffcient evidence of the presumed fact. ${ }^{41}$

In justification of the constitutionality of this definition, the commentary notes that "the Code will not establish a presumption unless the basic facts standing alone are strongly probative of the presumed fact in light of general experience, and unless the presumption does not cast an unfair burden on the defendant." 42 Examples of Code presumptions are: where a child under the age of eighteen is removed from the custody of its parent, that proof that the child's age was less than eighteen years gives rise to a presumption "that the actor knew the child's age or acted in reckless disregard thereof;" 43 and with regard to the receipt of stolen property by a dealer, knowledge is presumed from his having "received stolen property in another transaction within the year preceding the transaction charged." 44 Although there might be some question as to the sufficiency of the rational connection involved in certain of the presumptions, nothing in Tot or the cases preceding it suggests that the Code presumptions are unconstitutional in their effect. These presumptions will serve as useful referents for subsequent analysis, since their validity is no longer clear.

Two cases recently decided by the Supreme Court appear to place severe strictures upon the operation of statutory presumptions in criminal cases. United States $v$. Gainey ${ }^{45}$ involved a conviction for carrying on "the business of a distiller or rectifier without having given bond as required by law." 46 Section 5601(b)(2) of the Internal Revenue Code of 1954 provides that proof of the presence of the accused at a still while the business of a distiller was being conducted "shall be deemed sufficient evidence to authorize conviction, unless the defendant explains such presence to the satisfaction of the jury . . ." $47 \mathrm{Al}$ -

41 Moder Penar. Code, § 1.12(5) (Prop. Off. Draft 1962).

42 Modec Penal Code, § 1.13, comment at 117 (Tent. Draft No. 4, 1955).

$43 I d$. at $\$ 212.4$.

$44 I d$. at $\S 223.6(2)(\mathrm{b})$. Other presumptions appear in sections 5.06(2), 5.06(3), 223.7(1), 223.8, 230.3(3), and 251.2(4).

45380 U.S. 63 (1965).

46 72 Stat. 1398-99 (1958), 26 U.S.C. § 5601(a)(4) (1964).

47 72 Stat. 1398-99 (1958), 26 U.S.C. \& 5601(b)(2) (1964). 
though the presumption seems to shift the burden of persuasion to the accused, the judge charged the jury that even should the accused fail to explain his presence satisfactorily the jury was not required to convict, rather that the law merely declared that the jury may, "if it sees fit," convict upon evidence of presence alone. ${ }^{48}$ The Fifth Circuit reversed on the ground that the inference from presence to "carrying on" was insufficient to satisfy the due process requirement of Tot.49 The Supreme Court reversed. ${ }^{.0}$ Noting that the rationality of an inference was an empirical question much more within the competence of Congress than the judiciary and that the offense described included any act connected with distilling, the Court concluded: "Legislative recognition of the implications of seclusion [of an illegal still].only confirms what the folklore teaches-that strangers to the illegal business rarely penetrate the curtain of secrecy. We therefore hold that $\S 5601(\mathrm{~b})(2)$ satisfies the test of Tot $v$. United States . . .."r1

A few months later, however, in United States $v$. Romano, ${ }^{52}$ the Court recurred to the issue of rational connection in striking down a presumption sister to that in Gainey for lack of inferential strength. The crime involved was possession, custody, or control of an unregistered still; again unexplained presence was declared sufficient evidence to support a conviction..$^{53}$ The Court observed that unlike "carrying on," "possession" is only one of several functions that one present at a still might be performing, hence there was insufficient rational connection. ${ }^{54}$ In reaching this conclusion the Court repeatedly adverted to cases decided prior to enactment of the presumption holding presence insufficient evidence of possession to justify a conviction. ${ }^{55}$

Before discussing the effects of these cases two further aspects of Gainey must be mentioned. It was there contended that the presumption was unconstitutional because it impinged upon the trial judge's powers over the judicial proceeding. ${ }^{56}$ Noting that the "Constitution places in the hands of the trial judge the responsibility for safeguarding the integrity of the jury trial, including the right to have a case withheld from the jury when the evidence is insufficient as a

48380 U.S. 63 (1965).

48 Barrett v. United States, 322 F.2d 292 (5th Cir. 1963).

50380 U.S. at 71 .

51 Id. at 67-68.

52382 U.S. 136 (1965).

53 Id. at 137. The statute appears at 72 Stat. $1398-99$ (1958), 26 U.S.C. $\S 5601($ a)(1), (b)(1) (1964).

54382 U.S. at $139-41$.

55 Id. at $140,141$.

se 380 U.S. at 68. 
matter of law to support the conviction," the Court construed the statute as mere permission to the judge, rather than any compulsion upon him, to submit the case to the jury when the only evidence is possession and indicated that such a submission was reviewable. ${ }^{57}$ Moreover, implying that a further constitutional stricture existed, the Court noted that the presumption did not prevent the jury from being properly instructed as to reasonable doubt, and that the judge had correctly charged that the jury could acquit if it found that the Government had not proved guilt beyond a reasonable doubt. ${ }^{58}$ Both of these subsidiary holdings came in response to Mr. Justice Black's contention in dissent that the presumption violated several constitutional provisions. Thus they appear to have a constitutional basis rather than status as rules governing the federal judiciary. ${ }^{59}$

In neither Gainey nor Romano did the Court make clear which type of presumption the statute created. It did, however, recognize that the presumption was patterned after that upheld in Yee Hem v. United States; ${ }^{60}$ and it is reasonably clear from that case that the presumption was understood to shift both burdens to the accused. ${ }^{61}$ Moreover, whatever ambiguity remains is mitigated by the Court's discussion of the Gainey presumption in terms of certain constitutionally prohibited effects which this particular presumption avoided, thereby indicating that any type of presumption with such effects would be unconstitutional. The following discussion will suggest that Gainey and Romano have two principal results: (1) presumptions prescribing the quantum of evidence necessary for the prosecutor to get to the jury cannot constitutionally disadvantage the accused more than he would be had the presumption not existed; and (2) presumptions shifting the burden of persuasion to the accused are unconstitutional.

Earlier it was seen that certain presumptions establish a prima facie case to enable the prosecutor to get his case to the jury. For such presumptions to be effective the quantum of evidence required by the presumption must be less than that required by ordinary judicial standards for sufficient evidence (evidence upon which a rational jury could find guilt beyond a reasonable doubt). ${ }^{62}$ Romano, however, seems to imply that the inferential strength constitutionally required for a presumption is the same as that required by the judicial

57 Id. at 68 .

58 Id. at $68-69$.

$59 \mathrm{Id}$. at $74-88$.

60268 U.S. 178 (1925), cited in 380 U.S. at 64 n.2.

61268 U.S. at 184-85.

62 See 9 Wigmore, Evidence $\$ 2494$ (3d ed. 1940), and authorities cited note 17 therein. 
standard. The principal authorities marshalled by the Court to support its conclusion that there was no "rational connection" are cases in the Supreme Court and lower federal courts holding as a matter of law that presence is insufficient evidence of possession. ${ }^{63}$ Typical is the Court's statement that:

The United States has presented no cases in the courts which have sustained a conviction for possession based solely on the evidence of presence. All of the cases which deal with this issue and with which we are familiar have held presence alone, unilluminated by other facts, to be insufficient proof of possession. ${ }^{64}$

Since the Court was fully aware that the presumptions were enacted to overcome these very precedents ${ }^{65}$ it would appear that the Court has rejected its dicta in $T o t$ and established an identity between constitutional and judicial standards.

One argument against accepting this interpretation of Romano is that the inferential strength of the Romano presumption is probably not even that of a preponderance of the evidence and thus would not satisfy even the test of the Tot dictum; but there is no indication that the Court recognized this fact. More troublesome is reconciling identity of the standards with the holding in Gainey that the judge could refuse to send the case to the jury solely on evidence of unexplained presence, for if the standards are identical the judge would be required by the judicial standard alone to send the case to the jury in such circumstances. There is language which suggests, however, that the Gainey rule permitting judicial disregard of the presumption applies only when the inferential weight neither clearly satisfies nor fails to satisfy the judicial standard.66 In such a case congressional determination that the basic fact is of high probative value is given some weight by permitting the judge to submit the case to the jury on evidence of the basic fact alone if he agrees with Congress. Although such judicial discretion makes for a rather clumsy system, it would be even more difficult to rationalize judicial discretion if the constitutionally required weight for a presumption were merely a preponderance of evidence. In that case there seems to be no standard by which

63382 U.S. at 140,141 n.7.

$64 I d$. at 141 .

65 Id. at 142 .

68 "Yet it is precisely when courts have been unable to agree as to the exact relevance of a frequently occurring fact in an atmosphere pregnant with illegality that Congress' resolution is appropriate." 380 U.S. at 67. 
a judge could decide whether to submit the case to the jury. The only other reconciliation of the two cases would require viewing Romano as modifying Gainey by establishing the identity of the constitutional and judicial standards, thus overruling those portions of the Gainey opinion dealing with judicial discretion and the weight to be given Congressional empirical determinations. The Court, however, clearly viewed Gainey and Romano as completely consistent. ${ }^{67}$

Although the result seemingly reached by the Court is quite radical, there is a strong case to be made in its support. As previously discussed, a presumption which sends the case to the jury when the state of the evidence is such that a rational jury could not find guilt beyond a reasonable doubt, yet demands that the jury be instructed as to reasonable doubt, clearly relies for its effect on the expectation that the jury will disregard that instruction. Indeed, when coupled with an authorizing instruction the presumption is tantamount to inviting the jury to do so. Such a device is hardly conducive to a rational or just jury system. ${ }^{68}$

In spite of the requirement of greater inferential strength in presumptions, there is one other way in which the prosecutor might benefit from a presumption which depends upon the jury to give effect to a prescribed inference. If the jury is instructed that the Congress or legislature regards the basic fact as sufficient evidence to justify a conviction they are quite likely to give great weight to that fact. ${ }^{69}$ Thus a prosecutor receives a bonus for making out his case. Gainey and Romano, however, substantially deprive statutory criminal presumption of even this effect in the federal courts at least, for while approving the judge's instruction in Gainey, the Court made it clear that "better practice" would be to omit from the charge any reference to the statute. ${ }^{70}$ But an instruction which merely called attention to presence as one circumstance to be considered as persuasive would be, as the Court itself observed, no more than is permissable absent any presumption. ${ }^{71}$ This "bonus" to the prosecutor is thus likely to occur only in state courts.

At this point it is useful to recur to the Model Penal Code to observe the full effect of Gainey and Romano. First, it would appear that many of the Code presumptions could be attacked as unconstitutional due

67382 U.S. at 139-40.

68 Moder. Penal Code, § 1.13, comment at 111, 116-17 (Tent. Draft No. 4, 1955).

69 See United States v. Gainey, 380 U.S. 63, 74-88 (1965) (Black, J., dissenting).

$70 \mathrm{Id}$. at 71 n.7.

$71 \mathrm{Id}$. at 70 . 
to lack of requisite inferential strength. For example, from evidence that a child was younger than eighteen years a jury could not always find beyond a reasonable doubt that the person who removed the child from the custody of its parent knew that the child was younger than eighteen years; ${ }^{72}$ the child might, for instance, be seventeen. That this presumption is designed to comport with the rational connection test of Tot is no guarantee that it could survive the application of Gainey and Romano. Second, the Code cannot require that the issue of the existence of a presumed fact go to the jury, unless perhaps the basic fact is clearly sufficient evidence of the presumed fact. ${ }^{73}$ Finally, instructing the jury that the law declares that the basic fact is sufficient evidence is contrary to the Court's notion of "better practice," but for the present at least this remains federal, not constitutional doctrine. Little, then, would appear to remain either of the Code's general definition or of some of its specific presumptions.

The second principal effect of Gainey appears to be the constitutional proscription, contrary to the implication in Tot, of any presumption which shifts the burden of persuasion to the accused. Although the language of the Gainey presumption seems to shift this burden, the Court went out of its way to show that the burden remained upon the Government. ${ }^{74}$ In part this seems to be a response to Mr. Justice Black's contention in dissent that the presumption deprived the accused of his right to a trial by jury because it involved telling the jury that certain evidence shall be sufficient to convict. ${ }^{75}$ But had either the majority or the dissenters been willing to acknowledge the possibility that the burden of persuasion could be shifted, the contention that there was deprivation of right to trial by jury would be fragile, for it is only unexplained presence that is sufficient to convict, and the jury would be completely free to evaluate the explanation.

Unfortunately the Court was probably unaware of the necessary implications of its language, hence it is difficult to predict its reaction should the issue of the validity of a shift of the burden of persuasion be squarely presented. Of course there have been several instances when presumptions shifting the burden have been approved, but even

72 Model Penal Code, § 212.4 (Prop. Off. Draft 1962).

73 See text accompanying notes 68-69 supra. With regard to the type of presumption which depends for its effect upon establishing an evidentiary threshold for getting the issue of the existence of the presumed fact to the jury, it should be noted that by raising the standard for inferential strength the Court appears to have disapproved sub silento the results reached in several of its own precedents. See cases cited notes 4-5 supra.

74380 U.S. at 68-71.

75 Id. at 77-78. Cf. State v. Lawrence, 120 Utah 323, 234 P.2d 600 (1951). 
in these cases it does not seem to have been argued to the Court that such a shift was in itself unconstitutional. ${ }^{76}$ Prediction becomes even more difficult in light of the nature of the arguments, both for and against constitutionality, since they must rest upon the vaguest of notions-"fairness to the accused." This turns upon resolution of one of the issues most plaguing the present Court, how to balance the need of society for effective law enforcement with the desire to avoid mistaken convictions of the innocent. ${ }^{77}$ It should be emphasized, however, that neither of the policies of rational jury control or prevention of harassment militate against a shift in the burden of persuasion, provided the burden of going forward is not shifted. The only identifiable consequence of a permanent shift in the burden of persuasion on an issue is that juries would find it easier to convict because any doubt on the issue would be resolved against the accused. But perhaps the permanent shift of this risk to the accused is sufficiently contrary to our traditions to be considered a violation of due process. ${ }^{78}$

There remains one type of presumption to be examined in light of Gainey and Romano: that shifting the burden of going forward on penalty of the accused's having the issue of the existence of the presumed fact foreclosed against him. Depending upon the willingness and ability of the accused to go forward, such a presumption has a greater or lesser adverse effect upon him than a presumption shifting the burden of persuasion. If the accused fails to produce evidence after the burden is shifted, the effect is more serious since the jury has no choice but to find the presumed fact. If the accused goes forward with the evidence, however, the presumption completely disappears, whereas a shift in the burden of persuasion appears to be permanent. In view of these effects two minimum requirements would seem to be necessary to prevent gross unfairness and harassment; the presumption should satisfy the comparative convenience test and some other test which would assure that the prosecution had produced substantial incriminating evidence before the shift in burden takes place. In addition, such a presumption would be more palatable if the burden to be carried by the accused were no more than producing a quantum of evi-

76 See cases cited note 9 supra.

77 See, e.g., Escobedo v. Illinois, 378 U.S. 478 (1964); Fay v. Noia, 372 U.S. 391 (1963); Gideon v. Wainwright, 372 U.S. 335 (1963). See also Barrett v. United States, 322 F.2d 292, 296 (5th Cir. 1963).

78 See McCormICK, Evidence 661-62 (1954). 
dence upon which a rational jury could find the nonexistence of the presumed fact more probable than its existence. ${ }^{79}$

With regard to a presumption that met these criteria it is still necessary to inquire whether the Gainey-Romano rational connection and judicial discretion requirements are applicable and whether the policies against shifting the burden of persuasion would result in constitutional proscription of this type of presumption as well. The former requirements would, of course, seriously weaken the effect of the presumption, but there seems to be no reason to apply them. Both appear to be a response to the presumption which amounted to an invitation to the jury to convict on rationally insufficient evidence. Here there is no such problem, for the jury is instructed to take as given the presumed fact and proceed to a rational evaluation of the other evidence. Or if the accused has adequately gone forward no additional instructions are necessary at all.

The existence of a constitutional principle prohibiting any shift in the burden of persuasion presents greater difficulties. If the right to a jury trial includes the right to have the existence of each element of the crime proven beyond a reasonable doubt foreclosure would appear to be an unconstitutional sanction. Moreover, a presumption sanctioned by foreclosure could result in a virtual directed verdict of guilty should the accused admit the existence of the basic fact and all elements of the crime, except the presumed fact, but introduce no evidence. As was seen with regard to shifting the burden of persuasion, however, such considerations are only a part of an overall evaluation of due process notions of fairness. While it is difficult to make many conclusive statements about such an inquiry, it is possible to sharpen the issue. Only if there is a right not to produce evidence can it be said that the accused is injured by shift in the burden of going forward, which unlike the shift in burden of persuasion is temporary; for it is only in case of non-production that foreclosure will operate. If fairness involves such a right it must be because some significant risk of nonexistence of evidence or of self-incrimination is being placed upon the accused. The comparative convenience test, however, precludes this shift except when the accused would have easy access to the required evidence, hence he cannot be burdened with any significant risk of not being able to produce the evidence. As to the possibility of the defendant being able to produce only self-incriminating evidence, the Supreme Court in both Yee Hem and Gainey rejected the contention that

79 Compare Model Penal Code, $\S 1.13$ at 8 (Tent. Draft No. 4,1955 ) (alternative proposal of the Reporter). 
the accused was deprived of this fifth amendment right by a shift in either burden. ${ }^{80}$ Consequently there appear to be no substantial grounds supporting any right not to produce evidence.

There is even less reason for finding the existence of such a right if affirmative defenses are still valid devices. Neither Gainey nor Romano adverted to affirmative defenses, hence their status is once again in doubt. It was, however, suggested in the opinion of the court of appeals in Gainey that only the historically accepted defenses such as insanity and self-defense were presently constitutionally acceptable as affirmative defenses. ${ }^{81}$ This would be a certain, though inconsistent, way to resolve the present tension, otherwise Congress could constitutionally make presence at an unregistered still a crime and require the accused to prove as an affirmative defense that he was not in possession or control of the still. ${ }^{82}$

It is appropriate to conclude this discussion of criminal statutory presumptions by noting the existence of a logical difficulty which underlies not only the judicial evaluation of presumptions but suffciency of evidence and judicial notice as well. All of these notions necessarily assume the ability of the judiciary to make difficult empirical judgments with accuracy. Justice Stewart paid passing respect to this problem in Gainey when he noted that deference to Congress was appropriate in matters empirical. But even he felt called upon to support the accuracy of the inference by reference to "folklore." 83 However, the readiest solution to this empirical problem, acceptance of legislative competence, is equally distressing; for it appears that the legislative branch is not in these cases making a considered judgment as to the relationship between one fact and another. Rather, legislative action is a response to difficulty experienced in securing convictions. ${ }^{84}$

80 Gainey v. United States, 380 U.S. 63, 70-71 (1965); Yee Hem v. United States, 268 U.S. 178,185 (1925). But see dissent of Mr. Justice Douglas in Gainey v. United States, 380 U.S. at 71-74. It should not be forgotten that presumptions which shift either the burden of going forward or the burden of persuasion do place unique pressures upon the accused to testify, and may in the future run counter to the expanding protections of the privilege against self-incrimination.

81 Barrett v. United States, 322 F.2d 292, 296 (5th Cir. 1963).

82 "It may be that the Congress has the power to make presence at an illegal still a punishable crime, but we find no clear indication that it intended to so exercise this power." 382 U.S. at 144.

83380 U.S. at 67-68. Mr. Justice Stewart's source of folklore was an excellent account of the art of moonshining circa 1870-1880. ATKInson, AFTER THE MOONSHINERs, BY ONE of THE RAIDERS (1881). Its relevance to modern techniques of organized, mobile, urban and rural moonshining is open to some question. Assuming its relevance, however, had the Court consulted this authority in the Romano case it would have found passages suggesting that stills were almost always matters of joint proprietorship of all involved. Id. at 26-27.

841958 U.S. CODE CoNG. \& AD. News 4580. 
With this in mind, the defendants in Gainey countered the Government's reference to greater legislative competence by observing that such competence should only be deferred to when it had been truly exercised. ${ }^{85}$ But it is only a short step from such an inquiry to the accused's introduction of evidence to show that the legislative judgment, while once accurate, is now obsolete. The complications would be enormous.

For the most part the above dilemma is unavoidable. Even abandoning the "rational connection" test for one which would permit the shift of the burden of persuasion only when substantial incriminating evidence had been adduced ${ }^{86}$ would not mitigate the empirical difficulty. Whether certain facts are incriminating is also an empirical inquiry. However, this seems a less pretentious judgment for the courts to make and does focus more on the legitimate end of the "rational connection" test-prevention of harassment.

In summary, several distinct policies appear to underlie recent decisions altering the tests for determining the constitutionality of statutory criminal presumptions. The desire to promote rational jury verdicts has apparently resulted in the demise of presumptions which establish rules of prima facie evidence except insofar as the rational connection does not clearly fail to meet the judicial standard of sufficiency of the evidence. And there is strong reason to suspect that presumptions purporting to shift the burden of persuasion to the accused will meet with judicial disapproval, for the permanent shift of the risk of non-persuasion to the accused even on one element of the crime is apparently regarded as unfair. The most secure presumption would seem to be one shifting the burden of going forward supported by the sanction of foreclosure. When hedged by comparative convenience and some test forcing production by the prosecution of incriminating evidence the accused is protected from risk of non-existence of evidence and harassment. In short such a presumption does not appear to offend any policy which the Court has sought to promote, while it does serve the legitimate end of ease of law enforcement. But presumptions which cannot be so defended-and these are commonmay now be avoided entirely or have effect only as additional instructions to the jury.

85 Brief for Respondents, p. 4, United States v. Gainey, 380 U.S. 63 (1965).

86 See text accompanying note 27 supra. 